\title{
SYMPOSIUM ON UNAUTHORIZED MILITARY INTERVENTIONS FOR THE PUBLIC GOOD
}

\section{UNAUTHORIZED MILITARY INTERVENTIONS FOR THE PUBLIC GOOD: A RESPONSE TO HAROLD KOH}

\author{
Kimberley N. Trapp*
}

In his contribution to this Symposium, Harold Koh exhorts international lawyers to "seriously engage the debate" regarding the lawfulness (or at least the legal defensibility) of humanitarian intervention ("HI"). ${ }^{1}$ The aim of this essay is to take him up on that plea and sketch an alternative approach to the one that he advances. In so doing, I will focus on international law rather than U.S. domestic law.

\section{Kob's Argument}

Koh proposes that $\mathrm{HI}$ be conceptualized in terms of an affirmative defense to the charge of an unlawful use of force in breach of Article 2(4) of the United Nations Charter. Koh draws on the International Law Commission (ILC)'s Articles on State Responsibility and the circumstances precluding wrongfulness ("CPW") of distress, necessity, and countermeasures. Existing literature ably addresses the infeasibility of relying on these models while remaining true to the structure and underlying logic of the secondary rules of state responsibility. ${ }^{2}$ And of course, the ILC Articles expressly do not permit reliance on countermeasures to preclude the wrongfulness of a breach of Article 2(4) of the UN Charter. ${ }^{3}$

Nevertheless, there is a normative argument to be made here. Koh suggests that international law should "serve human purposes - including the protection of human rights, not just the territorial sovereignty of states." 4 I could not agree more. Indeed, as I have argued elsewhere, an account of state sovereignty that acknowledges that sovereignty serves the interests (and activities) of those subject to it is an increasingly important part of the modern discourse in international law. In respect of HI, this means that a state's sovereignty (and concomitant right to

* Senior Lecturer in Public International Law, Faculty of Laws, University College London.

${ }^{1}$ Harold Hongju Koh, Humanitarian Intervention: Time for Better Law, 111 AJIL UnBound 287 (2017).

${ }^{2}$ See Federica Paddeu, Excusing Humanitarian Intervention - A Reply to Jure Vidmar, EJIL:TAlk! (Apr. 27, 2017); Chris O’Meara, United States' Missile Strikes in Syria: Should International Law Permit Unilateral Force to Protect Human Rights?, EJIL:TALk! (Apr. 18, 2017); Chris O'Meara, Should International Law Recognize a Right of Humanitarian Intervention? 66 INT'L \& CoMP. L.Q. 441 (2017).

${ }^{3}$ Int'l Law Comm'n, Draft Articles on Responsibility of States for Internationally Wrongful Acts, with Commentaries art. 50(1)(a), UN Doc. A/56/10 (2001). Article 26 of the ILC Articles also precludes reliance on CPWs in respect of the breach of jus cogens norms, but there is of course debate as to whether it is Article 2(4) or merely the prohibition of aggression which is jus cogens.

${ }^{4}$ Koh, supra note 1 , at 288.

\footnotetext{
The American Society of International Law and Kimberley N. Trapp (C) 2017. This is an Open Access article, distributed under the terms of the Creative Commons Attribution licence (http://creativecommons.org/licenses/by/4.0/), which permits unrestricted re-use, distribution, and reproduction in any medium, provided the original work is properly cited.
} 
territorial integrity) should not, for its own sake, shield a state so as to provide it with the (legal and physical) space within which to violate individual rights to life and physical integrity. ${ }^{5}$

Whether these arguments on sovereignty justify establishing a further exception to Article 2(4) or accepting that (in respect of responses to humanitarian crises only) CPWs might excuse an otherwise unlawful use of force, the devil is in the details. And it is in respect of the details that I regrettably part ways with Koh.

\section{Evaluating the Argument}

The threshold or trigger condition for lawful HI, on Koh's account, is a humanitarian crisis that "creates consequences significantly disruptive of the international order ... that would likely soon create an imminent threat to the acting nations (which would give rise to an urgent need to act in individual and collective self-defense under UN Charter Article 51)." "Furthermore, the use of force should be for "genuinely humanitarian purposes [and be] necessary and proportionate to address the imminent threat," while improving the humanitarian situation and terminating "as soon as the threat is abated." In defining the conditions of lawful HI, Koh is conflating a rather controversial conception of anticipatory self-defense with HI.

Leaving aside for the moment the rather surprising suggestion that $\mathrm{HI}$ is simply a particular instantiation of national self-defense, the conflation has serious implications. In particular, Koh is both excluding a good many humanitarian crises from a right of response, and positing that the interests of acting states (or their allies) should be prioritized over the interests of the civilians whose suffering calls for a response-as long as there is some humanitarian benefit. But Koh asked international lawyers to "fashion a better law" which "serves human purposes." I would have expected the "better law" to serve the purposes of those humans who are now suffering at the hands of their own government, not those subject to the jurisdiction of states who may one day in the future suffer. This may well be the political reality-that states will not participate in $\mathrm{HI}$ as a matter of policy unless they are principally serving their own (and their population's) interests. But to limit HI, as a matter of law, to operations which first and foremost serve the national security interests of acting states, is an entirely different matter.

Let us begin with the exclusion of certain crises from the right to intervene by states with the relevant financial and military resources to do so, viewed particularly from the perspective of unilateral U.S. intervention (as Koh reminds us that, for better or worse, "in the international order, there is only one United States, and whoever is President, the United States plays a critical role as a balance wheel of the international system"8). On Koh's account, there are humanitarian crises to which the United States could not respond because the crises would not affect its national interests or those of its allies (defined in reference to Article 51 UN Charter). Consider the crisis in Darfur. While there have indeed been massive refugee flows and some destabilization of regional peace and security, the risk of proliferation of chemical weapons (or indeed any other weapons of mass destruction) has not been a feature of the crisis. As a result, and despite the overwhelming nature of the humanitarian catastrophe, it only potentially poses an imminent threat to states within the region or reach of refugee flows, and this assuming we accept a broad definition of anticipatory self-defense. Assuming no request for assistance from states facing such an "imminent threat," the United States could not have responded in Darfur on Koh's account, even

\footnotetext{
${ }^{5}$ Kimberley N. Trapp, Actor-Pluralism and the "Turn to Responsibility" in the Jus ad Bellum: "Unwilling or Unable" in Context, 2 J. UsE ForCE INT'L L. 1 (2015).

${ }^{6}$ Harold Hongju Koh, The War Powers and Humanitarian Intervention, 53 Houston L. Rev. 971, 1011 (2016).

${ }^{7}$ Id. In respect of this last criterion, Koh seems to be suggesting that the intervention must end as soon as the imminent threat to the acting state is abated. If this is so, it further highlights the extent to which the right of intervention is focused on the interests of the acting state, as discussed below.

${ }^{8}$ Koh, supra note 1 , at 291 .
} 
had it been inclined to do so. While "America First" may well be the defining feature of Donald Trump's foreign policy agenda, prioritizing the interests of the acting state(s) in the legal calculus of $\mathrm{HI}$ runs counter to the vast majority of moral and legal thinking on this issue. ${ }^{?}$

In respect of the right of response to a humanitarian crisis by any state (in particular regionally proximate states), we can well imagine a scenario in which the threat to the civilian population is territorially limited, does not occasion cross-border refugee flows (but instead only produces internally displaced persons), and is principally the result of the use of conventional weapons. However catastrophic the crisis for civilians on the ground, it does not pose an imminent threat to any state and therefore does not meet the threshold trigger for HI proposed by Koh.

Koh purports to define the conditions for the lawfulness of $\mathrm{HI}$ per se, but is instead defining the lawfulness of a very broadly defined right to use force in anticipatory self-defence, with (in the best case) ancillary humanitarian benefits. In particular, he proposes that the necessity and proportionality of the unauthorized military intervention be measured against the imminent threat to outside states, not the humanitarian crisis.

This brings us to the second implication of conflating defensive and humanitarian paradigms: it allows acting states to prioritize their own defensive interests. Let us revise the scenario in which the threat to the civilian population is territorially limited, does not occasion cross-border refugee flows (only internally displaced persons), and is principally the result of the use of conventional weapons. But in this case, the instability occasioned by the humanitarian crisis creates the space for the proliferation of weapons of mass destruction. This crisis would meet Koh's trigger condition (in that it may engage acting states' interests under a broadly defined right of anticipatory self-defense).

It goes without saying that the response to the proliferation risk would not (and indeed by design should not, on Koh's account) address the humanitarian crisis occasioned by the use of conventional weapons. This is another version of the "too narrow" problem addressed above. Even accepting for the moment that some lawful $\mathrm{HI}$ is better than no lawful HI, or that in some cases the imminent threat to acting states is coextensive with the threat to civilians in the target state, a necessity and proportionality calculus measured against the purpose of responding to the imminent threat to the acting state skews the calculus in favor of that state's own self-interest. This is true even if some humanitarian benefit is necessary to meet Koh's third condition for lawful self-defense. Part of the difficulty is the measure of proportionality Koh relies on. Given that he is operating under a self-defense paradigm, he adopts the ICJ's approach to proportionality in the jus ad bellum context, which is to say a teleological approach (measuring defensive force against the purpose of that defensive force). ${ }^{10} \mathrm{~A}$ teleological approach to proportionality permits consideration of a narrow range of interests-principally the acting state's defensive interests. At the in bello level, there are also serious implications of defining $\mathrm{HI}$ in terms of national self-defense. In particular, the extent of permissible civilian casualties on the ground are defined in reference to the anticipated military advantage, ${ }^{11}$ which again reflects the acting state's national security interests— not the interests of the civilians whose suffering occasioned HI.

\footnotetext{
${ }^{9}$ It is a long-time feature of writing in both moral and legal approaches to HI that the intervening state must be acting for a "proper purpose" or with a "right intention," defined in terms of the interests of the beneficiary population. See, e.g., W.E. HaLL, TreatisE on INTERNATIONAL LAW 265 (2d ed. 1884).

${ }^{10}$ Legality of the Threat or Use of Nuclear Weapons, Advisory Opinion, 1996 ICJ Rep. 226, paras. $41-44$ (July 8). See also Armed Activities on the Territory of the Congo (Dem. Rep. Congo v. Uganda), 2005 ICJ Rep. 168 (Kooihmans, J., separate opinion) para. 34 (Dec. 19); Legality of the Threat or Use of Nuclear Weapons, Advisory Opinion, 1996 ICJ Rep. 226 (Higgins, J., dissenting), para. 5 (July 8).

${ }^{11}$ See Protocol Additional to the Geneva Conventions of 12 August 1949, and relating to the Protection of Victims of International Armed Conflict (Protocol I) art. 51(5)(b), June 8, 1977, 1125 UNTS 3 [hereinafter API].
} 
Ultimately, the problem is that Koh wants to serve both defensive and humanitarian ends at the same time. He cannot have it both ways. If the starting point is the right of self-defense, the defensive ends are much more likely to prevail over the humanitarian ones.

\section{Which Public, What Good?}

Below, I sketch an alternative approach to Koh's. My starting premise is that an account of lawful HI must at least begin with the human interests of those suffering immediate harm, not the human interests of those who are far away and would likely soon suffer an imminent threat. The relevant interests include that the intervention be effective in its protective aims; enduring; and avoids (or at least minimizes) ancillary harm.

To be clear, placing the beneficiary population's interests at the centre of the legal analysis does not preclude the acting state from accounting for its own interests. ${ }^{12}$ This is particularly true if we adopt the proportionality analysis more prevalent in the human rights law and jus in bello contexts, which balances positive impacts against negative impacts. ${ }^{13}$ The positive impacts would be measured principally in reference to the interests of the beneficiary population and of the international community as a whole, at least to the extent that an $\mathrm{HI}$ which protects a civilian population upholds values that are core to the international legal system. But an unauthorized military intervention for "genuinely humanitarian purposes" may also involve both positive and negative impacts for the acting state(s).

As to negative impacts, acting states very clearly have an interest in minimizing the danger to the men and women participating in the operation. The intervening state's presence on the ground in territory that is engulfed in armed conflict may make for a more effective intervention that can best minimize ancillary harm, but it would put that state's soldiers at greater risk than would (for instance) a purely aerial campaign. The result is that the largest scale interventions for "genuinely humanitarian purposes" in the last twenty-five years- the U.S./U.K. (and at one point French) no-fly zones in Iraq in the wake of the First Gulf War, the NATO campaign in Kosovo in 1999, and the Security Council-authorized operations in Libya in 2011 (UNSCR 1973)—have been principally aerial, involving a higher risk of errors and resulting civilian casualties. ${ }^{14}$ While this doesn't necessarily raise difficulties in respect of a legal test that requires that the interests of the victims of the humanitarian catastrophe be prioritized in any proportionality calculus, it does raise serious concerns about the ability of states to apply this test.

Equally, it need not be the case that the national security interests that Koh is concerned with fall completely outside the scope of a proportionality calculus that is built around the beneficiary population's interests. For instance, an acting state's interest in "prevent[ing] and deter[ring] the spread and use of chemical weapons" 15 is

12 See, e.g., Eyal Benvenisti, Sovereigns as Trustees of Humanity: On the Accountability of States to Foreign Stakeholders, 107 AJIL 295 (2013).

13 See, e.g., API art. 51(5)(b). Proportionality is also often coupled with an analysis of rational connection to legitimate aims and whether the measure is the "least harmful" alternative available to achieve that aim. While these elements are very clearly relevant in analyzing the legitimacy (moral or legal) of HI (see Ben Saul, US Missile Strikes Expose the Untenable Status Quo in International Law, CHATHAM House (Apr. 26, 2017)), they need not be addressed here separately. In particular, rational connection is accounted for by the interest in the effectiveness of the unauthorized military intervention, while the "least harmful" element is accounted for in the beneficiary community's interest in the minimization of ancillary harm. Koh accounts for rational connection in his requirement that an intervention "demonstrably improve the humanitarian situation," but this condition is in addition to the intervention being necessary and proportionate to address the imminent threat to acting states.

${ }^{14}$ See, e.g., Committee Established to Review the NATO Bombing against the Federal Republic of Yugoslavia, Final Report to the Prosecutor of the International Criminal Tribunal for the Former Yugoslavia paras. 63-70; Nick Hopkins, Libya: NATO Admits Civilian Deaths in Tripoli Air Raid, Guardian (June 20, 2011). See also Simon Chesterman, Just War or Just Peace? Humanitarian Intervention AND INTERNATIONAL LAW 220-23 (2002).

${ }^{15}$ Donald Trump's statement in respect of the targeted military strike on the air base in Syria from where the chemical attack was launched on April 6, 2017 stated in M.R. Gordon et al., Dozens of U.S. Missiles Hit Air Base in Syria, N.Y. Times (Apr. 6, 2017). 
coextensive with the interest of the beneficiary population in being protected against the use of chemical weapons by its own government. To the extent that the "vital security interests" 16 of acting states overlap with the beneficiaries' interests in an enduring and effective intervention that avoids or minimizes ancillary harm, there is nothing objectionable in there being an ancillary benefit to those national interests. What is objectionable is defining the purpose of $\mathrm{HI}$ in terms of those national interests.

\section{Conclusion}

Koh has called on "international lawyers to develop a better rule to evaluate the legality of unilateral humanitarian intervention." 17 While international lawyers (in particular those of an academic persuasion with the professional luxury of not having a client's interests to serve or represent) may well at times think of themselves as somewhere close to philosopher kings, they do not, acting in their private capacities, make international law. States both make and apply the law. And even with a "better law" devised by international lawyers, including a properly weighted proportionality calculus that focuses on the interests of the most vulnerable humans, there are serious concerns as to whether acting states can objectively balance their own national interests against the positive impacts of an unauthorized military intervention for "genuinely humanitarian purposes."

This is particularly the case given the accountability mechanisms that operate in respect of the intervening state or states. An intervening state's government (as the primary decision-maker in respect of $\mathrm{HI}$ ) is first and foremost accountable to its domestic electorate. While that electorate may not be terribly engaged in the broader "to intervene or not to intervene" question, the number of "body bags" produced by an intervention will most certainly engage the voting public. As a result, states are likely to disproportionately protect their own interests; commentators frequently highlight the limits of unilateral decision-making in expressing concerns about legalizing (or legally justifying) HI. ${ }^{18}$ Even Koh acknowledges in some measure that there is cause for serious skepticism as to whether a fully and objectively costed decision to engage in an unauthorized military intervention for the public good can be arrived at unilaterally. Perhaps this cannot occur until states with the resources and military capability to engage in such operations are ruled by philosopher kings. And history tells us that philosopher kings are, at best, few and far between.

\footnotetext{
${ }^{16} \underline{I d}$.

${ }^{17}$ Koh, supra note 1 , at 287.

18 See Louis Henkin, Kosovo and the Law of "Humanitarian Intervention", 93 AJIL 824, 825 (1999). Koh of course prefers multilateralism, as reflected in his fourth point on the lawfulness of HI, but it is not a necessary condition, serving instead an evidentiary purpose.
} 